Vol. 10 (2): 389-400 (2020)

\title{
A COMPARATIVE STUDY FOR SODIUM BOROHYDRIDE DEHYDROGENATION AND ELECTROOXIDATION ON CERIUM AND COBALT CATALYSTS
}

\author{
Tülin Avci Hansu ${ }^{1,2}$, Aykut Çaglar¹, Omer Sahin², Hilal Kivrak ${ }^{1 *}$ \\ ${ }^{1}$ Van Yuzuncu Yil University, Faculty of Engineering, Department of Chemical Engineering, Van, 65000, Turkey; \\ ${ }^{2}$ Siirt University, Faculty of Engineering, Department of Chemical Engineering, Siirt, 56100, Turkey; \\ *Corresponding Author Hilal Kivrak, e-mail: hilalkivrak@gmail.com; hilalkivrak@yyu.edu.tr;
}

Received April 2020; Accepted May 2020; Published June 2020;

DOI: https://doi.org/10.31407/ijees10.220

\begin{abstract}
In the present study, $\mathrm{Co} / \mathrm{CNT}$ and $\mathrm{Ce} / \mathrm{CNT}$ catalysts are prepared via sodium borohydride $\left(\mathrm{NaBH}_{4}\right)$ reduction method. $\mathrm{Co} / \mathrm{CNT}$ and $\mathrm{Ce} / \mathrm{CNT}$ catalysts are examined to the dehydrogenation and electrooxidation of $\mathrm{NaBH}_{4}$. $\mathrm{NaBH}_{4}$ dehydrogenation activities of these Co/CNT and Ce/CNT catalysts are performed in alkaline environment. $5 \% \mathrm{Co} / \mathrm{CNT}$ catalyst exhibits superior hydrogen evolution compared with other catalysts. Activation energy is calculated using Arrhenius equation. Initial rate for this catalyst is found as $1700 \mathrm{ml} \mathrm{H}_{2} \mathrm{~g}^{-1}$ cat $\min ^{-1}$. As a result of the kinetic calculations, the activation energy of the catalyst is calculated as $44,68775 \mathrm{kj} / \mathrm{mol}$. The degree of reaction (n) is found to be 0.5 by trial and error. In conclusion, $5 \% \mathrm{Co} / \mathrm{CNT}$ catalyst is a promising catalyst for hydrogen production from $\mathrm{NaBH}_{4}$. Cyclic voltammetry $(\mathrm{CV})$ analysis is utilized to examine the electrochemical activity of the catalysts for $\mathrm{NaBH}_{4}$ electrooxidation. $0.1 \% \mathrm{Co} / \mathrm{CNT}$ catalyst has $0.38 \mathrm{~mA} \mathrm{~cm}{ }^{-2}\left(3181 \mathrm{~mA} \mathrm{mg}^{-1} \mathrm{Co}\right)$ specific activity.
\end{abstract}

Keywords: Dehydrogenation, electrooxidation, Ce, Co, Sodium borohydride 